\title{
The Basics of Agricultural BMPs in Northern Florida and Southwestern Georgia ${ }^{1}$
}

\author{
Martha C. Monroe and Charles Barrett ${ }^{2}$
}

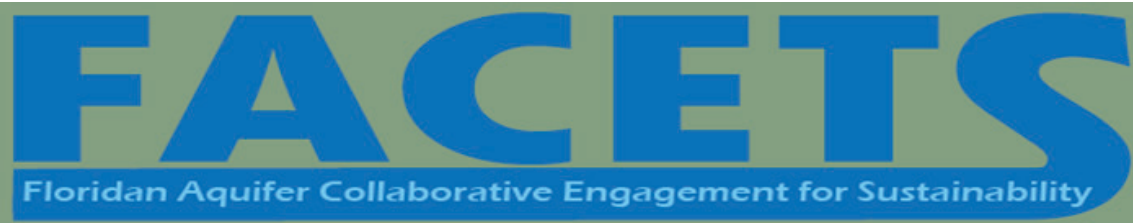

Best management practices, or BMPs, are cost-efficient processes and activities that improve many aspects of daily life, from healthcare to food service. Agricultural BMPs aim to reduce water use and water quality impacts on farms and ranches while improving or maintaining soil. Additional BMPs focus on forestry practices and lawn care. In Florida, the Department of Agriculture and Consumer Services (FDACS) adopts by rule specific BMP manuals as a part of the state's water quality policy.

Farming today is not merely a matter of plowing the land, planting seeds, and harvesting. It is also a business and must remain profitable to stay in business. Harvesting equipment can cost up to $\$ 750,000$. Center pivot irrigation systems generally cost over $\$ 100,000$ to install and $\$ 5,000$ every year to maintain and operate (Figure 1 ). To keep the cost to consumers reasonable, there is not much room for input cost increases, bad weather, international competition, labor issues, or new pests and diseases. This is a high-risk business with little room for error.

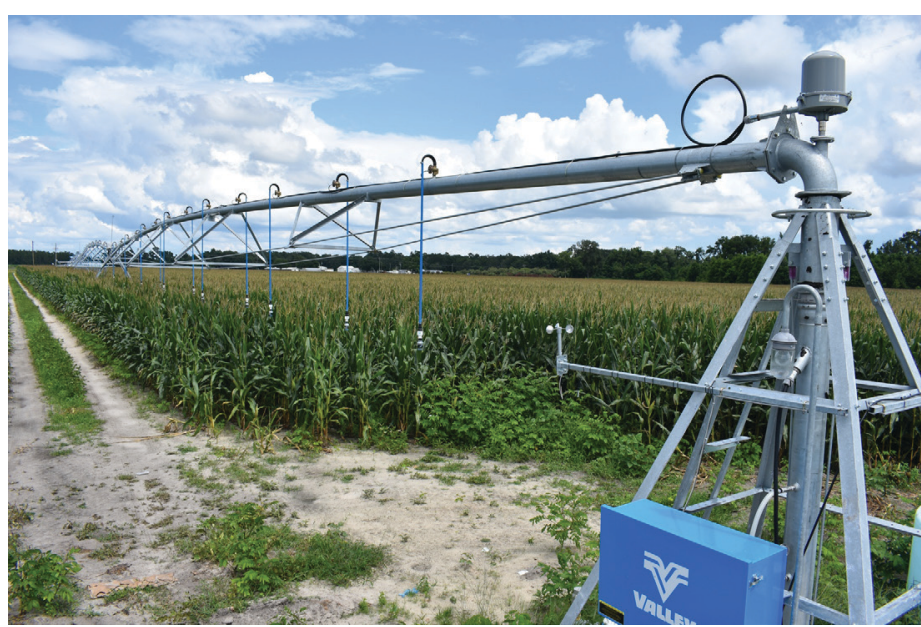

Figure 1. Center pivot irrigation system with low pressure drop nozzles increase crop water uptake efficiency.

Credits: Charles Barrett, UF/IFAS

Any farming practice has the potential to create an environmental impact-a consequence of supporting modern lifestyles. Depending on the climate and soil type, the same practice can have a negligible impact or a considerable one. BMPs represent guidelines for improved practices that help maintain productivity while minimizing both harm to the environment and debilitating costs. In this way BMPs

1. This document is FR437, one of a series of the School of Forest, Fisheries, and Geomatics Sciences, UF/IFAS Extension. Original publication date June 2021. Visit the EDIS website at https://edis.ifas.ufl.edufor the currently supported version of this publication.

2. Martha C. Monroe, professor, School of Forest, Fisheries, and Geomatics Sciences; and Charles Barrett, UF/IFAS Extension regional specialized agent, water resources; UFIFAS Extension, Gainesville, FL 32611.

The Institute of Food and Agricultural Sciences (IFAS) is an Equal Opportunity Institution authorized to provide research, educational information and other services only to individuals and institutions that function with non-discrimination with respect to race, creed, color, religion, age, disability, sex, sexual orientation, marital status, national origin, political opinions or affiliations. For more information on obtaining other UF/IFAS Extension publications, contact your county's UF/IFAS Extension office. U.S. Department of Agriculture, UF/IFAS Extension Service, University of Florida, IFAS, Florida A \& M University Cooperative Extension Program, and Boards of County Commissioners Cooperating. Nick T. Place, dean for UF/IFAS Extension. 
help communities balance environmental and economic goals. We all want clean water for drinking and recreating and at the same time we all want low-cost food to eat and economically healthy towns to call home. Sustaining healthy rural communities means keeping producers in the business of growing food while also protecting our water resources. In some areas we may be approaching the point where we can no longer maximize both goals to everyone's satisfaction and will have to make trade-offs.

\section{Examples of Best Management Practices}

Many BMPs are common-sense guidelines. When it comes to irrigation systems on row crops like corn, cotton, and peanuts, BMPs suggest that the systems be maintained, cleaned, calibrated, and checked for efficient and uniform delivery of water to the whole field (FDACS 2015). If fertilizer is applied through the irrigation system, the lines should be checked throughout the season and cleaned at the end of the season. These activities make irrigation systems more efficient and maximize crop growth.

Determining how much water to apply to a field is not a simple matter because rainfall and soil characteristics must be taken into account. Rainfall is not evenly distributed or perfectly timed for growing crops, and rain does not always fall at the ideal rate for crops to benefit. If the combination of irrigation and rainfall results in too much water, fertilizer may be carried deeper into the ground than crop roots can reach, making it more likely that nutrients will be leached into the groundwater or run off into streams and lakes. Irrigation management is ideal when water is applied frequently for short durations. This BMP can be adjusted with rainfall to minimize leaching and decrease crop stress (Figure 2).

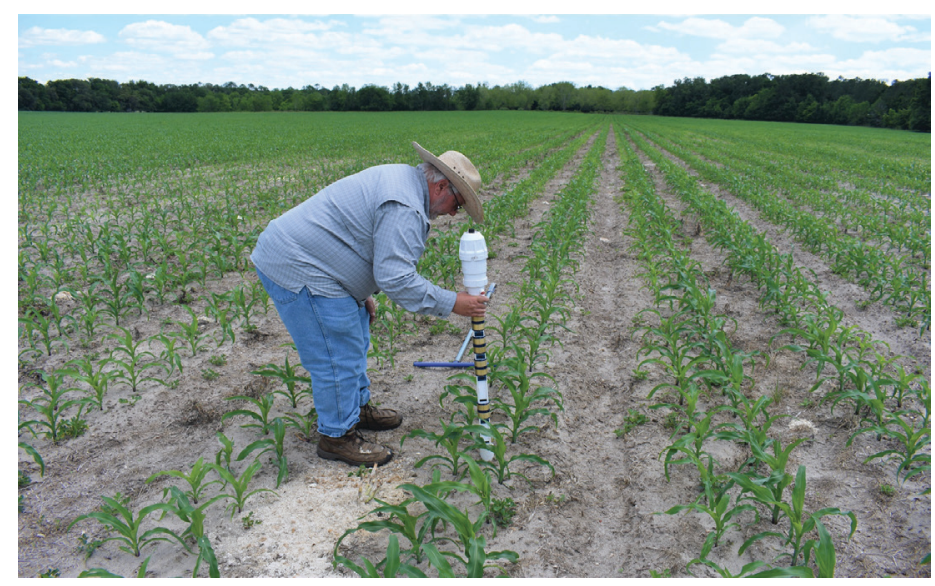

Figure 2. Joel Love, BMP outreach specialist, installs a soil moisture sensor for a corn grower.

Credits: Charles Barrett, UF/IFAS
Soils should be tested each year to help determine the needed nutrients and adjust the soil $\mathrm{pH}$. Crops vary in their demand for nutrients depending on the growing season, growth habit, and density. Farmers can alter the placement, rate, and timing of fertilizer applications to meet BMPs and match crop demand.

Farmers using precision agriculture rely on GPS (Global Positioning System) to maximize production on their land by planting in carefully spaced, straight rows. Precision agriculture also entails carefully metering seed and applying the right amounts of nutrients at the right rates and at the right times. In some cases, such as variable rate applications, farmers are changing the rate of nutrient or water application to match crop, soil, and moisture needs across their field.

Some farmers use conservation tillage to grow crops in cover crop residue, which helps to reduce soil erosion, conserve soil moisture, and reduce weed competition.

Farmers also manage the edges of their fields by maintaining grassed routes rather than bare ground to move machinery and to reduce runoff. At the stream banks and wetlands, producers often use buffer strips, keeping these edges in trees or native vegetation to help contain soil and nutrients and provide wildlife habitat. All of these BMPs protect water quality and quantity by reducing or slowing the rate at which water and nutrients leave the farm or by maximizing crop uptake.

\section{Gains for the Environment and the Economy}

BMPs include only those activities determined by the state agriculture agency to be economically feasible for producers. While some, like using less fertilizer, might appear to save farmers money, these practices often require more labor or specialized equipment to implement. Some BMPs have been easily adopted, such as using GPS, testing soil, and upgrading irrigation systems. These BMPs provide the benefits of reducing input costs, increasing efficiency, and conserving water. Everyone wins when agriculture BMPs are implemented because we get food security and water quality/quantity benefits.

Some BMPs require a significant investment to begin implementation, such as planting trees or installing a fence near a stream or converting to precision agriculture. When a producer is interested in investing in a more expensive BMP, they may be eligible for cost-share, which means the producer invests in the improvement and is reimbursed 
for a portion of that investment. Those funds come from state and federal governments. For example, a producer may spend $\$ 75,000$ on equipment that places fertilizer directly at the root zone. The producer pays this upfront cost and is then reimbursed, in some cases up to $75 \%$ of the cost, up to 6 months later. The producer incurs the cost of maintaining the equipment into the future,takes on the extra management and cost of using this new method, and benefits from increased fertilizer use efficiency on the farm and sometimes from increased yield as well.

\section{But do they work?}

Agricultural BMPs are developed through an iterative process of research and practice. If the recommended practices are implemented as intended, they should conserve water or improve water quality. Training opportunities and assistance are available to help producers implement BMPs, but there are likely to be differences in soil, slope, crops, etc. that lead to variations in outcomes. Fortunately, research that will enable us to determine the regional water quality and quantity outcomes of broad implementation of BMPs is now underway. While the results are not in yet, we do know the BMPs are moving us in the right direction by conserving water and reducing nutrient losses.

Across the region, all water users have a responsibility to protect the environment and conserve water. Currently, agricultural BMPs are voluntarily adopted by farmers because they make sense and in the long run should make agriculture more sustainable. This is good news for communities and the environment because farmland provides open space for recharging the aquifer. As more farmers implement these strategies, we will learn more about which gains are achievable and which will require additional conversations, negotiation, and financial incentives to meet.

\section{Cited}

FDACS [Florida Department of Agriculture and Consumer Services]. 2015. Water Quality/Quantity Best Management Practices for Florida Vegetable and Agronomic Crops, 2015 edition. FDACS-P-01266. Tallahassee, FL: FDACS. 